\title{
Intravenous Insulin Decreases Urinary Albumin Excretion in Long-term Diabetics with Nephropathy
}

\author{
N. J. Christensen, H. J. G. Gundersen, C. E. Mogensen, and E. Vittinghus \\ Department of Internal Medicine and Endocrinology, Herlev Hospital, Herlev, Institute of Experimental Clinical Research, \\ University of Aarhus, Medical Department I, Aarhus Amtssygehus, and 2nd University Clinic of Internal Medicine, \\ Aarhus Kommunehospital, Aarhus, Denmark
}

\begin{abstract}
Summary. The effect of intravenous injection of insulin on heart rate, plasma noradrenaline and urinary excretion rates of albumin and beta-2-microglobulin was examined in 10 long-term diabetics, 5 of whom had albuminuria. - In patients without albuminuria intravenous injection of insulin resulted in changes similar to but less pronounced than those previously observed in short-term diabetics: albumin excretion, plasma noradrenaline and heart rate increased, creatinine excretion decreased significantly. Intravenous injection of insulin increased heart rate but not plasma noradrenaline in long-term diabetics with albuminuria. Arterial blood pressure did not change after insulin. Contrary to expectation insulin decreased urinary albumin excretion (from 418 to $312 \mu \mathrm{g} / \mathrm{min}, 27$ per cent) in these patients. There was a marked decrease in urinary excretion rates of beta2-microglobulin and creatinine (55 and 17 per cent, respectively) after insulin. - The decrease in albumin excretion after insulin in diabetics with albuminuria is most likely due to renal vasoconstriction. The absence of a rise in albumin excretion after insulin may be due to severe morphological changes in glomeruli in these patients.
\end{abstract}

Key words: Arterial blood pressure, blood glucose, cardiovascular, heart rate, insulin, long-term diabetes, nephropathy, neuropathy, noradrenaline, proteinuria, urinary albumin excretion.

It is now known that insulin has marked acute effects on sympathetic nervous activity and the cardiovascular system. In short-term diabetic subjects intravenous injection of insulin increases plasma noradrenaline $[1,2,3]$ and heart rate $[3,4]$ and decreases peripheral and renal blood flow as well as glomerular filtration rate $[3,5]$. Furthermore, insulin induces hypovolaemia $[3,6]$ and increases urinary excretion of albumin $[5,7]$.

The cardiovascular effects of insulin are not due to hypoglycaemia [3]. Except for the changes in renal blood flow and in glomerular filtration rate they occur even in diabetics in whom blood glucose concentration after insulin is maintained at unchanged levels by glucose infusion [7].

The aim of the present study was to examine cardiovascular effects of insulin in long-term diabetics. Patients with normal and elevated albumin excretion, respectively, were selected in order to investigate the influence of glomerular damage on the insulin induced increase in albumin excretion.

\section{Patients}

Ten long-term juvenile diabetic patients were studied. From previous studies five of them were known to have elevated urinary excretion rates of albumin (> $25 \mu \mathrm{g} / \mathrm{min}$ ). Pertinent clinical data are given in Table 1 . Most of the diabetic patients had signs of neuropathy. They were all treated with insulin twice a day, but had their last dose of insulin 24 hours before the investigation. Furthermore, they were asked to eat two pieces of bread beyond their usual diet the evening before the investigation to achieve a somewhat elevated blood glucose level. Informed consent was obtained from all subjects.

\section{Procedure}

The patients were examined in the morning after an overnight fast. They rested in the sitting position, standing up only to void. They drank $45 \mathrm{ml}$ of water every $15 \mathrm{~min}$, starting 1 hour before the experiment was initiated and continued during the whole experiment.

After a resting period of half an hour urinary albumin and beta-2-microglobulin excretion were measured in two $30 \mathrm{~min}$ periods before and three $45 \mathrm{~min}$ periods after insulin. Eight IU of 
Table 1. Clinical data in 10 male juvenile diabetics

\begin{tabular}{|c|c|c|c|c|c|c|c|c|}
\hline Patients & Age (years) & $\begin{array}{l}\text { Per cent } \\
\text { ideal body } \\
\text { weight }\end{array}$ & $\begin{array}{l}\text { Blood } \\
\text { pressure } \\
\text { mm Hg }\end{array}$ & $\begin{array}{l}\text { Diabetes } \\
\text { duration } \\
\text { (years) }\end{array}$ & $\begin{array}{l}\text { Retinopathy } \\
\text { stage }\end{array}$ & $\begin{array}{l}\text { Neuropathy } \\
\text { Deep tendon }^{a} \\
\text { reflexes }\end{array}$ & $\begin{array}{l}\text { Biothe- } \\
\text { siometry } \\
\text { volts }^{b}\end{array}$ & $\begin{array}{l}\text { Usual daily } \\
\text { insulin dose, } \\
\text { IU }\end{array}$ \\
\hline \multicolumn{9}{|c|}{$\begin{array}{l}\text { With } \\
\text { albuminuria }\end{array}$} \\
\hline 1 & 28 & 97 & $115 / 70$ & 13 & Background & Present & 21 & 56 \\
\hline 2 & 31 & 99 & $120 / 80$ & 15 & Background & Absent & 40 & 48 \\
\hline 3 & 25 & 133 & $125 / 90$ & 15 & Background & Present & 28 & 112 \\
\hline 4 & 34 & 113 & $120 / 80$ & 13 & None & Absent & 28 & 72 \\
\hline 5 & 30 & 93 & $185 / 110$ & 16 & Background & Present & 36 & 52 \\
\hline \multicolumn{9}{|c|}{$\begin{array}{l}\text { Without } \\
\text { albuminuria }\end{array}$} \\
\hline 6 & 32 & 84 & $100 / 70$ & 11 & Background & Absent & 32 & 40 \\
\hline 7 & 35 & 104 & $110 / 80$ & 27 & Prolif. & Present & 24 & 56 \\
\hline 8 & 24 & 110 & $115 / 80$ & 10 & None & Present & 16 & 56 \\
\hline 9 & 33 & 103 & $120 / 90$ & 17 & Background & Absent & 17 & 96 \\
\hline 10 & 33 & 106 & $135 / 95$ & 20 & Background & Present & 30 & 80 \\
\hline
\end{tabular}

Patients with albuminuria had albumin excretion rates greater than $25 \mu \mathrm{g} / \mathrm{min}$

a Patellar and Achilles-tendon reflexes

${ }^{b}$ Normal values are less than 15 volts

insulin (Leo Neutral) was given as a bolus injection during one min, just after termination of the two 30 min periods. Plasma noradrenaline and adrenaline were measured before and $45 \mathrm{~min}$ after the injection of insulin. Blood glucose concentration, heart rate and arterial blood pressure were measured at $15 \mathrm{~min}$ intervals during the examination.

\section{Methods}

Urinary concentration of albumin and beta-2-microglobulin (Phadebas ${ }^{\circledR}$ beta $_{2}$-microtest) were measured by radioimmunoassays $[8,9]$. The interassay coefficients of variation for urinary albumin and beta-2-microglobulin determinations on urine from normal subjects were 6.2 and 9.3 per cent, respectively. Plasma noradrenaline and adrenaline were measured by a double-isotope derivative assay [10]. Arterial blood pressure was measured indirectly by a sphygmomanometer. Plasma glucose was determined by an orthotoluidine method. Creatinine excretion was measured by a standard method. Vibratory perception threshold was measured in the big toe with a biothesiometer. We have previously shown that diabetics with elevated vibratory perception threshold values demonstrate both functional and biochemical signs of sympathetic denervation $[11,12]$.

Wilcoxon's test for paired samples and Student's t-test for paired samples were used for testing statistical significance [13].

\section{Results}

Blood glucose concentration decreased by about $100 \mathrm{mg} / 100 \mathrm{ml}$ after intravenous injection of insulin, but did not decline below normal fasting levels (Table 2).

In the five diabetics with albuminuria insulin decreased albumin excretion from a mean pre-insulin value of $418 \mu \mathrm{g} / \mathrm{min}$ to a mean post-insulin value of $312 \mu \mathrm{g} / \mathrm{min}$ (Table 3 , a mean decrease of 27 per cent, $2 \mathrm{P}=0.013)$. Urinary excretion of creatinine decreased 17 per cent in the same period $(2 \mathrm{P}=$ $0.0077)$. There was a marked decrease in urinary excretion rates of beta-2-microglobulin (mean 55 per cent, $2 \mathrm{P}=0.0023$ ).

In the five long-term diabetics without albuminuria the changes observed after insulin were similar, but less pronounced, than those found in short-term diabetics. Urinary albumin excretion increased from a mean value of $11.4 \mu \mathrm{g} / \mathrm{min}$ before to a mean value of $14.2 \mu \mathrm{g} / \mathrm{min}$ after insulin $(2 \mathrm{P}=$ 0.047 ). Urinary excretion of beta-2-microglobulin did not change significantly after insulin in these patients. Creatinine excretion decreased from a mean preinsulin value of $1.43 \mathrm{mg} / \mathrm{min}$ to 1.13 and $1.23 \mathrm{mg} /$ $\mathrm{min}$ in the first and second period after insulin (21 and 14 per cent, respectively, $2 \mathrm{P}=0.0032$ and $0.013)$. The corresponding values in the group of patients with albuminuria were 23 and 16 per cent, respectively.

There were no changes in plasma noradrenaline (mean $0.37 \mathrm{ng} / \mathrm{ml}$ in the sitting position both before and $45 \mathrm{~min}$ after insulin) and plasma adrenaline and in arterial blood pressure after insulin in the five diabetics with albuminuria, while heart rate increased significantly in the first 45 min period after insulin (from a mean value of $76 \pm 12$ (SE) to $83 \pm 16$ beats $/ \mathrm{min}, 2 \mathrm{P}=0.038$ ). Mean heart rate and mean plasma noradrenaline increased in patients without albuminuria from 75 to 84 beats/min and from 0.29 
Table 2. Mean blood glucose concentrations \pm SE $(\mathrm{mg} / 100 \mathrm{ml})$ obtained in 10 long-term diabetics with and without albuminuria at $15 \mathrm{~min}$ intervals in two $30 \mathrm{~min}$ periods before and three 45 min periods after intravenous injection of insulin. Results are mean values for each period except in the first post-insulin period

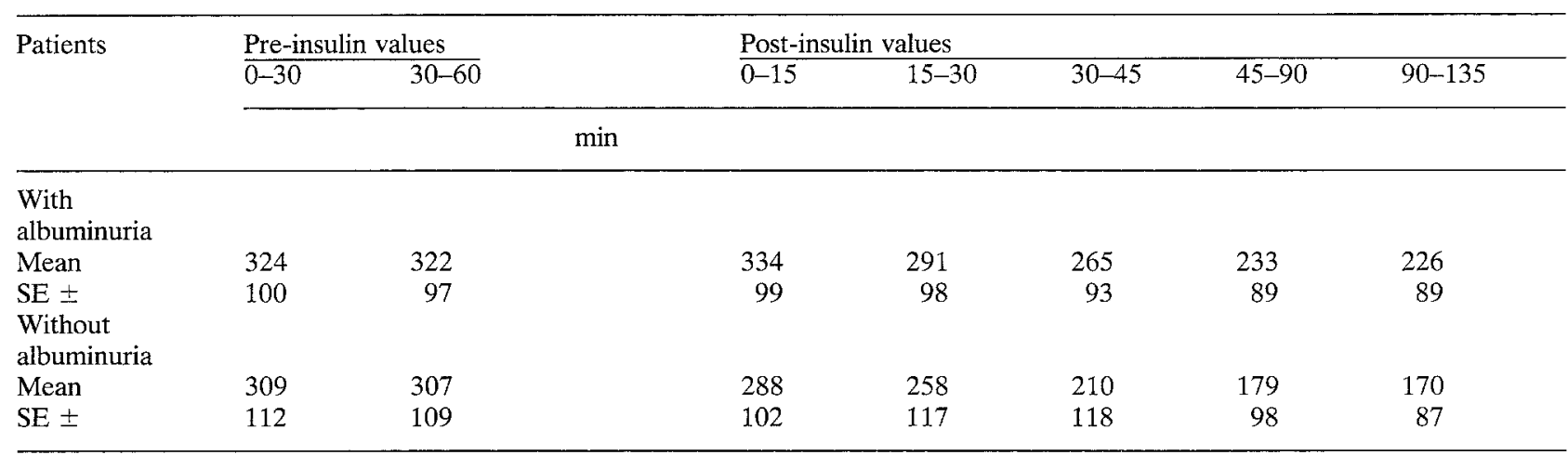

Table 3. Urinary excretion rates of albumin ( $\mu \mathrm{g} / \mathrm{min})$, beta-2-microglobulin ( $\mathrm{ng} / \mathrm{ml})$ and of creatinine ( $\mathrm{mg} / \mathrm{min}$ ) obtained in $5 \mathrm{long}$-term diabetics with albuminuria in two $30 \mathrm{~min}$ periods before and three $45 \mathrm{~min}$ periods after intravenous injections of insulin

\begin{tabular}{|c|c|c|c|c|c|c|}
\hline \multirow[t]{3}{*}{ Nos. } & & \multicolumn{2}{|c|}{ Pre-insulin values } & \multicolumn{3}{|c|}{ Post-insulin values } \\
\hline & & $\overline{0-30}$ & $30-60$ & $0-45$ & $45-90$ & $90-135$ \\
\hline & & \multicolumn{5}{|c|}{$\min$} \\
\hline 1 & $\begin{array}{l}\text { Albumin } \\
\beta-2 \text {-microglobulin } \\
\text { Creatinine }\end{array}$ & $\begin{array}{l}200 \\
66 \\
1.45\end{array}$ & $\begin{array}{l}209 \\
66 \\
1.57\end{array}$ & $\begin{aligned} 171 \\
51 \\
1.34\end{aligned}$ & $\begin{array}{c}158 \\
44 \\
1.31\end{array}$ & $\begin{array}{r}133 \\
37 \\
1.44\end{array}$ \\
\hline 2 & $\begin{array}{l}\text { Albumin } \\
\beta \text {-2-microglobulin } \\
\text { Creatinine }\end{array}$ & $\begin{array}{l}420 \\
67 \\
2.23\end{array}$ & $\begin{array}{l}420 \\
56 \\
1.92\end{array}$ & $\begin{array}{l}64 \\
16 \\
0.68\end{array}$ & $\begin{array}{l}270 \\
18 \\
1.55\end{array}$ & $\begin{array}{r}286 \\
12 \\
1.41\end{array}$ \\
\hline 3 & $\begin{array}{l}\text { Albumin } \\
\beta-2 \text {-microglobulin } \\
\text { Creatinine }\end{array}$ & $\begin{array}{l}122 \\
123 \\
1.49\end{array}$ & $\begin{array}{l}120 \\
151 \\
1.35\end{array}$ & $\begin{array}{l}88 \\
88 \\
1.04\end{array}$ & $\begin{array}{l}89 \\
78 \\
1.14\end{array}$ & $\begin{array}{l}86 \\
60 \\
1.32\end{array}$ \\
\hline 4 & $\begin{array}{l}\text { Albumin } \\
\beta \text {-2-microglobulin } \\
\text { Creatinine }\end{array}$ & $\begin{array}{c}140 \\
66 \\
1.34\end{array}$ & $\begin{array}{r}141 \\
84 \\
1.32\end{array}$ & $\begin{array}{l}116 \\
48 \\
1.27\end{array}$ & $\begin{array}{c}113 \\
33 \\
1.14\end{array}$ & $\begin{array}{r}128 \\
15 \\
1.23\end{array}$ \\
\hline 5 & $\begin{array}{l}\text { Albumin } \\
\beta \text {-2-microglobulin } \\
\text { Creatinine }\end{array}$ & $\begin{array}{r}1296 \\
57 \\
1.00\end{array}$ & $\begin{array}{l}1105 \\
91 \\
1.14\end{array}$ & $\begin{array}{l}959 \\
68 \\
1.00\end{array}$ & $\begin{array}{l}1040 \\
7 \\
0.96\end{array}$ & $\begin{array}{l}981 \\
7 \\
1.01\end{array}$ \\
\hline Mean & $\begin{array}{l}\text { Albumin } \\
\beta \text {-2-microglobulin } \\
\text { Creatinine }\end{array}$ & $\begin{array}{l}436 \\
76 \\
1.50\end{array}$ & $\begin{array}{c}399 \\
90 \\
1.46\end{array}$ & $\begin{array}{c}280 \\
54 \\
1.07\end{array}$ & $\begin{array}{l}334 \\
36 \\
1.22\end{array}$ & $\begin{array}{l}323 \\
26 \\
1.28\end{array}$ \\
\hline
\end{tabular}

to $0.39 \mathrm{ng} / \mathrm{ml}$ at $45 \mathrm{~min}$ after insulin, respectively ( $2 \mathrm{P}$ $=0.022$ and 0.031 ).

\section{Discussion}

The present study shows that urinary albumin excretion decreases after intravenous injection of insulin in long-term diabetics with albuminuria in contrast to the findings in short-term diabetics $[5,7]$ and in longterm diabetics without signs of nephropathy.

Renal blood flow and glomerular filtration rate were not measured in the present study, but, judged by the pronounced decrease in creatinine excretion, they were in all probability decreased after insulin in both groups of patients examined. In a previous study in which blood glucose was allowed to decline after insulin renal blood flow and glomerular filtration rate decreased markedly [5]. A decrease in renal blood flow and in glomerular filtration rate is the most likely explanation for the decrease in renal excretion rates of albumin after insulin in diabetics with albuminuria. In short-term diabetics vasoconstriction may tend to decrease albumin excretion, but other factors predominate, with the net effect that albumin excretion is increased. As discussed elsewhere $[5,7]$ 
the increase in albumin excretion after insulin is most likely of glomerular origin. It is possible that the absence of increase in renal albumin excretion in diabetics with albuminuria is due to morphological changes in glomeruli or in afferent and efferent vessels present in these patients.

The decrease in creatinine excretion in long-term diabetics was considerably more pronounced than previously observed in a group of short-term diabetics (19 versus 5 per cent, respectively (unpublished results). However, the experimental designs were not identical, particularly with respect to the position of the subjects and water intake.

In short-term diabetics arterial blood pressure either does not change after insulin or may even increase slightly $[3,5,7]$. Arterial blood pressure may decrease after insulin in patients with autonomic neuropathy $[14,15,16]$. In the present study there was no change in arterial blood pressure in diabetics with nephropathy even though there was no increase in plasma noradrenaline.

The normal rise in heart rate observed after insulin in diabetics with nephropathy and no change in plasma noradrenaline is not surprising because, in a previous study in rabbits, we showed that this action of insulin occurs independently of the autonomic nervous system [17].

Acknowledgement. This study was supported by grants from The Danish Medical Research Council and The Danish Heart Foundation.

The authors gratefully acknowledge the secretarial assistance of Mrs. R. Riis and the technical assistance of Mrs. Merete Møller and Mrs. Elin Bang.

\section{References}

1. Christensen NJ (1974) Plasma norepinephrine and epinephrine in untreated diabetics, during fasting and after insulin administration. Diabetes 23: 1-8

2. Christensen NJ, Alberti KGMM, Brandsborg O (1975) Plasma catecholamines and blood substrate concentrations: Studies in insulin induced hypoglycaemia and after adrenaline infusions. Eur J Clin Invest 5: 415-423

3. Gundersen HJ G, Christensen N J (1977) Intravenous insulin causing loss of intravascular water and albumin and increased adrenergic nervous activity in diabetics. Diabetes 26: 551-557

4. Page M McB, Smith R B W, Watkins P J (1976) Cardiovascular effects of insulin. Br Med J I: 430-432

5. Mogensen CE, Christensen NJ, Gundersen HJ G (1978) The acute effect of insulin on renal haemodynamics and protein excretion in diabetics. Diabetologia 15: 153-157

6. MacKay J D, Hayakawa H, Watkins P J (1978) Cardiovascular effects of insulin: Plasma volume changes in diabetics. Diabetologia 15: 453-457

7. Mogensen CE, Gundersen HJG, Christensen NJ (in press) The acute effect of insulin on heart rate, plasma noradrenaline and urinary albumin excretion: The role of changes in blood glucose. Diabetologia

8. Miles DW, Mogensen CE, Gundersen HJ G (1970) Radioimmunoassay for urinary albumin using a single antibody. Scand J Clin Lab Invest 26: 5-11

9. Evrin PE, Petersen PA, Wide L, Berggård J (1971) Radioimmunoassay of beta-2-microglobulin in human biological fluids. Scand J Clin Lab Invest 28: 439-444

10. Christensen NJ (1973) Plasma noradrenaline and adrenaline in patients with thyrotoxicosis and myxoedema. Clin Sci Mol Med 45: 163-171

11. Christensen NJ (1969) Spontaneous variations in resting blood flow, postischaemic peak flow and vibratory perception in the feet of diabetics. Diabetologia 5: 171-178

12. Christensen NJ (1972) Plasma catecholamines in long-term diabetics with and without neuropathy and in hypophysectomized subjects. J Clin Invest 51: 779-787

13. Documenta Geigy (1962) Scientific Tables, Sixth ed. Geigy AG, Basel

14. Miles D W, Hayter C J (1968) The effect of intravenous insulin on the circulatory responses to tilting in normal and diabetic subjects with special reference to baroceptor reflex block and atypical hypoglycaemic reactions. Clin Sci Mol Med 34: 419-430

15. Page MMcB, Watkins PJ (1976) Provocation of postural hypotension in diabetic autonomic neuropathy. Diabetes 25 : 90-95

16. Seyer-Hansen K (1977) Postprandial hypotension. Br Med J II: 1262

17. Jacobsen F, Christensen NJ (1979) Stimulation of heart rate by insulin: Uninfluenced by beta-adrenergic receptor blockade in rabbits. Scand J Clin Lab Invest 39: 253-256

Received: April 24, 1979,

and in revised form: October 16, 1979

Dr. N. J. Christensen

Medicinsk-endokrinologisk afd.

Herlev Sygehus

DK-2730 Herlev

Denmark 